\title{
The 2 Ga peraluminous magmatism of the Jacobina-Contendas Mirante Belt (Bahia) Brazil): Major and trace-element geochemistry and metallogenic potential
}

\author{
Michel Cuney ${ }^{\mathrm{a}}$, Pierre Sabatéb ${ }^{\text {, Philippe Vidal }}{ }^{\mathrm{c}}$, Moacyr M. Marinho ${ }^{\mathrm{d}}$ and Herbet Conceiçao ${ }^{\mathrm{d}}$ \\ "GREGU and GS CNRS-GREGU, BP 23, 54501, Vandoeuvre Cedex, France \\ ${ }^{b}$ ORSTOM, France and UFBA, CP 4021, Barra, Salvador, Bahia, Brazil \\ ${ }^{c} U A 10$ CNRS, 2 Rue Kessler, Clermont Ferrand, France \\ ${ }^{d} C B P M, C A B$, Salvador, Bahia, Brazil
}

(Received August 12, 1989; revised and accepted March 5, 1990)

\begin{abstract}
Cuniey, M., Sabaté, P., Vidal, Ph., Marinho, M.M. and Conceiçao, H., 1990. The 2 Ga peraluminous magmatism of the Jacobina - Contendas Mirante belt (Bahia-Brazil): major- and trace-element geochemistry and metallogenic potential. In: P. Le Fort, J.A. Pearce and A. Pêcher (Editors), Collision Magmatism. J. Volcanol. Geotherm. Res., 44: 123 - 141.
\end{abstract}

\begin{abstract}
The Jacobina - Contendas Mirante belt represents a Transamazonian ( $2 \mathrm{Ga}$ ), N-S, 500-km long, elongated orogenic domain in the central part of the São Francisco craton, Bahia state. Numerous syntectonic to post-tectonic peraluminous leucogranites were emplaced along the major structures of the belt. Their mineralogical and geochemical and some of their metallogenetic characteristics are very similar to their Hercynian and Himalayan equivalents. However, their average peraluminous index varies from one granitic pluton to another and biotite is, on average, slightly more magnesian in the Transamazonian leucogranites. Higher oxygen fugacity is indicated by the general occurrence of magnetite, the stability of allanite and sometimes epidote in most of the plutons and by biotite chemistry. The peraluminous magmatism of the Jacobina-Contendas Mirante belt results from crustal partial melting during a continental collision event at 2 Ga.

Trace-element geochemistry implies variable source composition and/or melting conditions for the different granitic plutons and some different facies within the same plutonic unit. The scarcity of ilmenite, the general occurrence of magnetite, and the relatively low peraluminous index of some of these granites suggest that graphite-beating sediments are not a significantly source material. From their mineralogical and geochemical characteristics, acid meta-igneous rocks such as the Sete Voltas TTG suite of presumed Archaean age, seem to represent a suitable source for these granites.

$\mathrm{Sn}, \mathrm{W}, \mathrm{Li}, \mathrm{F}$ and Be enrichment of most Transamazonian leucogranites is much weaker than in the mineralized Variscan equivalents. The Caetano - Aliança and Riacho das Pedras granites represent the most specialized granitic bodies. Beryl (emerald), molybdenite and scheelite mineralizations are related to some of these granites which intrude ultrabasic formations: the Campo Formoso and the Carnaiba granites. In many of these granites, uranium content is comparable to values measured in mineralized Hercynian leucogranites. The occurrence of hexavalent uranium minerals, mineralization and episyenitic alteration are favourable criteria for finding Variscan-type uranium ore deposits.
\end{abstract}

\section{Introduction}

Continental crustal thickening typically allows the generation of large amounts of crustal melts without the direct involvement of mantle material. Peraluminous leucogranites represent the most characteristic magmatic products generated during continental collision. These highly differentiated melts result from low degrees of melting of metamorphic material. Associated intermediate to basic plutonic rocks are typically lacking. In the Hercynian and Himalayan belts, peraluminous leucogranites form relatively narrow belts 
elongated over several hundreds of kilometres parallel to the major thrust planes. Peraluminous magmatism may also occur at passive margins but in much more limited volumes and is mainly represented by volcanic tuffs (Pichavant et al., 1988a, b).

Although the absence of well-developed peraluminous magmatism is insufficient to reject a continental collision setting, the presence of large volumes of syn- to late-tectonic peraluminous leucogranites may be used in conjunction with other geological evidence to signify the presence of ancient suture zones between continental masses in old orogenic belts. The existence of modern plate tectonic regimes during Archaean and early Proterozoic times is still a matter of considerable debate. The Transamazonian $(2 \mathrm{Ga}$ ) leucogranites of the Jacobina - Contendas Mirante belt, which forms an elongated belt over $500 \mathrm{~km}$ long in the central part of the Bahia state (Brazil), represents a rather unique domain for studying this problem (Figs. 1 and 2).

As peraluminous leucogranites result from partial melting of continental crust, the differences in their mineralogical and chemical compositions reflect the composition of the various igneous and/or sedimentary sources that have contributed to magma generation. Thus, the geochemical signature of the Transamazonian leucogranites is an important tool for evaluating the composition of the Archaean



Fig. 1. Simplified geological map of the Bahia state (Brazil) $I=$ Undifferentiated formations; $2=$ Contendas Mirante, Jacobina and Itapicuru Transamazonian volcanosedimentary belts; 3 = Salvador Curaçá and Atlantic coast belts; $4=$ Jequié Archaean crustal domain; 5 = Gaviào Archaean crustal domain; $6=$ major thrust faults. 


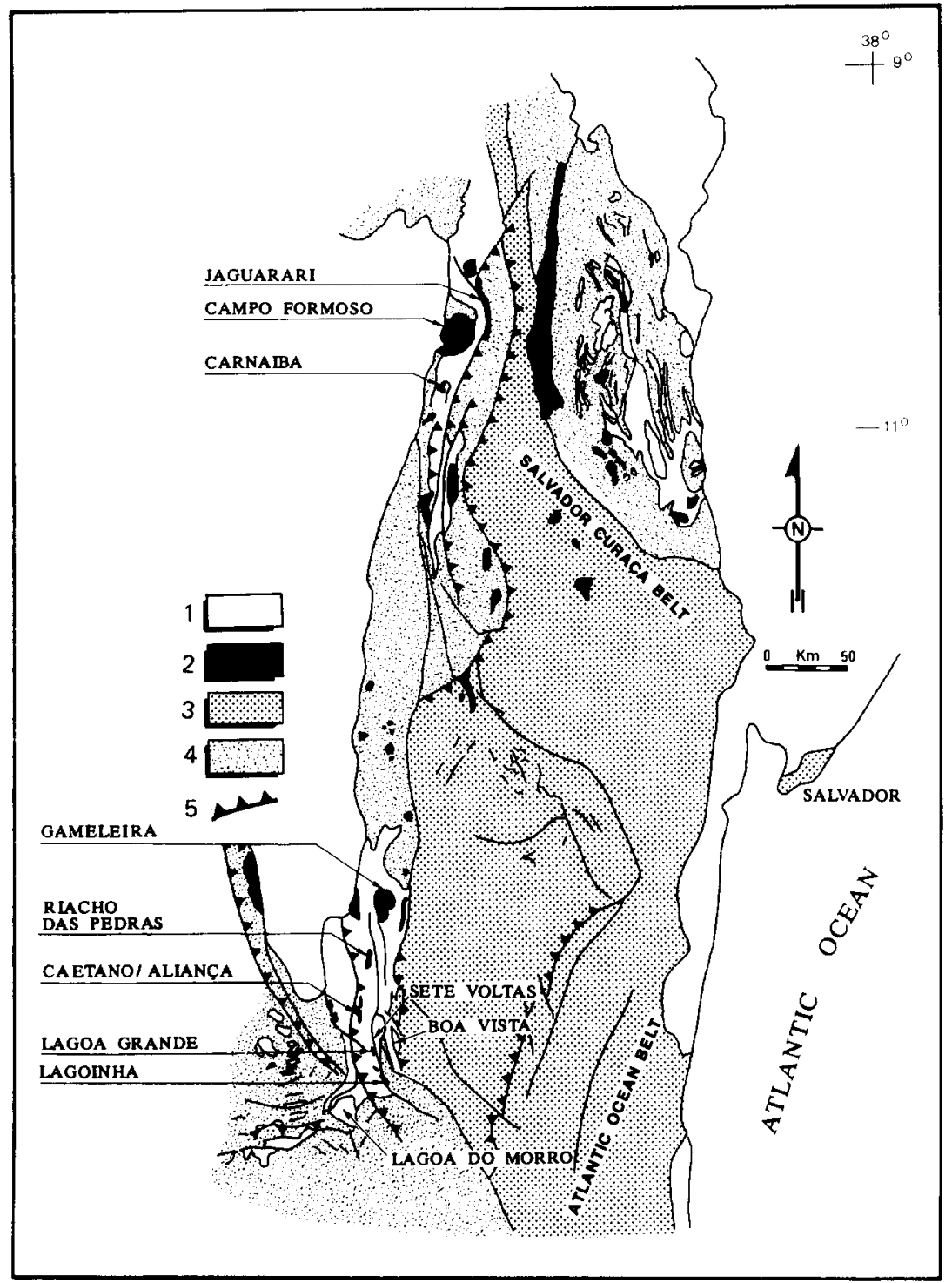

Fig. 2. Geological map of the Transamazonian Jacobina - Contendas Mirante belt with the location of the major granitic plutons. $l=$ Contendas Mirante Jacobina and Itapicuru Transamazonian volcanosedimentary belts; $2=$ Transamazonian granites; 3 = Jequié Archaean crustal domain and Salvador Curaçá-Atlantic coast belts; $4=$ Gavião Archaean crustal domain; 5 = major thrust faults.

crust, or the crust at the Archaean-Lower Proterozoic transition, depending of the age of the source material. This geochemical signature also has direct implications for the evaluation of the metallogenic potential of these granites.

To achieve these objectives, the mineralogy, major- and trace-element geochemistry of the
Transamazonian leucogranites have been characterized and compared with their Hercynian and Himalayan equivalents.

\section{Regional geology}

The Jacobina - Contendas Mirante volcanosedimentary belt is located in the eastern part of 
the São Francisco craton (Fig. 1). This part of the craton is free of tectonothermal events of Brasiliano age, unlike the western part (Espinhãço belt, Turpin et al., 1988). The Sào Francisco craton represents one of the largest pieces of Archaean and lower Proterozoic crust in South America and is mainly exposed in the state of Bahia. The lower Proterozoic Jacobina-Contendas Mirante belt, onented $\mathrm{N}-\mathrm{S}$ and about $500 \mathrm{~km}$ long, lies between two major Archaean crustal domains (Figs. 1 and 2): the Jequié domain, with the Atlantic coast mobile belt to the east, which is over $700 \mathrm{~km}$ in length from north to south; and the Gavião domain to the west.

The Jequié domain and the Atlantic coast mobile belt are composed of high to very high grade volcanosedimentary formations, charnockites and enderbites (Mascarenhas, 1973, 1976; Babosa, 1986); the protoliths of the Jequié formations have given $\mathrm{Rb} / \mathrm{Sr}$ dates of late Archaean age (2.7. Ga, Cordani et al., 1985) and, in the western part, metamorphosis of age Transamazonian (Wilson, 1987).

The Gavião domain is composed of a migmatitized gneiss-amphibolite complex corresponding to a volcanosedimentary association. It represents the basement of the Jacobina-Contendas Mirante supracrustal sequences. Several large Archaean domes, elongated north-south, composed of a trondhjemite-granite association similar to the classical Tonalite - Trondhjemite - Granodiorite (TTG) suites, are tectonically emplaced within the supracrustal sequences in the southern part of the Contendas Mirante belt: these include the Lagoa do Morro, Sete Voltas and Boa Vista domes. They probably represent the oldest lithologies in the São Francisco craton (3.1 and 3.5 Ga Rb/Sr age for the Lagoa do Morro and Boa Vista domes, respectively, Cordani et al., 1985).

Over twenty syn- to late-tectonic leucogranites intrude either the Gavião basement or the Jacobina-Contendas Mirante supracrustal sequences. The syntectonic emplacement of most of these granitic bodies is supported by their shape, which is elongated parallel to the major thrust planes, and by the magmatic foliation, parallel to ductile shear zones that are generally developed within the pluton at its eastern margin, and parallel to the foliation of the surrounding metamorphic rocks.

\section{The Jacobina belt}

In the Jacobina area (Fig. 1), the Archaean basement, composed of high grade metamorphic rocks (migmatites, itabirites, quartzites, calcsilicates and metabasic to ultrabasic rocks) is overthrust from east to west by the Serra de Jacobina series. The first phase of deformation was followed by an $\mathrm{E}-\mathrm{W}$ shortening with strike-slip tectonism leading to vertical fold axes and the horizontal structures were transformed into steep $\mathrm{N}-\mathrm{S}$ trending belts. The Jacobina series forms a narrow $(6-12 \mathrm{~km}$ wide), elongate belt over $200 \mathrm{~km}$ in length, composed of thick metaquartzite units, metaconglomerates, mica-schists, banded iron formations and intercalated meta-ultrabasic slices $100-300 \mathrm{~m}$ thick. According to Couto (1978), the micaschists may correspond to volcanic formations. The total thickness of the Jacobina series may reach $8 \mathrm{~km}$. In the micaschists, the metamorphic paragenesis varies from north to south from andalusite-kyanite to cordierite - anthophyllite - sillimanite - garnet.

Seven leucogranitic plutons have been recognized in the Jacobina area (Couto, 1978; Celino and Sabaté, 1988; Rudowski and Fonteilles, 1988). Two of them have been sampled, the Campo Formoso and the Carnaiba plutons (Fig. 2).

\section{The Contendas Mirante belt}

Two lithostratigraphic units have been recognized (Marinho et al., 1979, 1980): a lower unit composed of basalts and intermediate volcanics with intercalations of clastic and chemical sediments, and an essentially detrital 
upper unit. Metamorphism increases towards the Jequie block from low to medium grade. Two major phases of deformation have been recognized (Sabaté et al., 1980): westward overthrusting was followed by an $\mathrm{E}-\mathrm{W}$ shortening which rotated the previous structures towards the vertical. The horizontal structures generated during the first phase were progressively transformed into steep $\mathrm{N}-\mathrm{S}$ trending elongated belts. The Jequié block is overthrust onto the Gaviào block and the Contendas Mirante belt (Sabaté et al., 1988).

At least fifteen leucogranitic plutons have been recognized in the Contendas Mirante area (Marinho et al., 1979, 1980; Marinho and Sabaté, 1982; Conceição, 1986). Six of them have been sampled in the Contendas Mirante belt, from the Gameleira pluton in the north through the Riacho das Pedras, Aliança, Caetano and Lagoa Grande plutons to the Lagoinha pluton in the south.

Deformed and undeformed leucogranitic plutonic rocks of the Sete Voltas Archaean dome have been also studied. They represent one possible source material for the Transamazonian leucogranites. No isotopic data are presently available on these rocks, but they are of presumed Archaean age as they present the same lithological and tectonic characteristics as the Lagoa do Morro and Boa Vista domes.

\section{Petrography of the granites}

The granites are generally equigranular, fine to medium grained $(1-5 \mathrm{~mm})$; they are rarely porphyritic, unlike part of the Campo Formoso pluton. Subsolidus deformation may be important in some plutons. Three types of enclaves have been recognized: (1) enclaves of enclosing metamorphic rocks mostly located in the vicinity of the contact, but also as roof pendants, such as the serpentinite enclave (about $100 \mathrm{~m}$ wide) in the centre of the Carnaiba pluton (Couto, 1978); (2) small (about 1-10 $\mathrm{cm}$ ) biotite-rich layered enclaves most probably representing restitic material; and (3) enclaves of early-emplaced granites in later intrusions. Basic, microgranular enclaves have never been observed.

\section{Campo Formoso}

The Campo Formoso composite pluton is a circular, two-mica leucogranite, with a diameter of about $25 \mathrm{~km}$, mainly emplaced in the Archaean basement. The southern and eastern part of the granite intrudes serpentinites which form the basal contact of the Jacobina overthrust formations. Two main units have been recognized in the granite (Rudowski and Fonteilles, 1988; Rudowski, 1989). An early external fine to coarse grained unit, emplaced at the southern and eastern margins of the pluton, is characterized by an abundance of large muscovite megacrysts. The central unit, which represents the main part of the pluton, is porphyritic, richer in biotite and poorer in muscovite. Late garnet-bearing granites and aplopegmatites are widespread throughout the pluton. Only one emerald deposit occurs in the metasomatic zones developed at the contact between granitic pegmatites and ultrabasic rocks (Rudowski et al., 1987). A $\mathrm{Rb} / \mathrm{Sr}$ whole rock dating of the external fine grained unit (Torquato et al., 1978) gave an age of $1.97 \pm 0.02 \mathrm{Ga}$ with an initial ratio of $0.708 \pm 0.001$. A more recent $\mathrm{Rb} / \mathrm{Sr}$ whole rock dating for samples taken from both granitic units (Sabaté et al., 1990) gave the same age $(1.97 \pm 0.03 \mathrm{Ga})$, with an initial ratio of $0.706 \pm 0.003$.

\section{Carnaiba}

The Carnaíba granite represents a smaller, circular ( $4 \mathrm{~km}$ in diameter), homogeneous, and fine grained two mica leucogranite, emplaced in the Archaean basement (Rudowski and Fonteilles, 1988; Rudowski, 1989). The granite outcrops in a tectonic window in the Jacobina overthrust formations. Late garnet-muscovite granitic dykes are also widespread 
throughout the pluton (Rudowski et al., 1987). Numerous areas of emerald mineralizations are present in the ultrabasic bands, both in the basement and the overthrust cover. $\mathrm{Rb} / \mathrm{Sr}$ radiometric measurements give an age of $1.88 \pm 0.09 \mathrm{Ga}$ with an initial ratio of $0.733 \pm 0.018$ (Sabaté et al., 1990).

\section{Gameleira}

The Gameleira pluton is a nearly circular (20 $\mathrm{km}$ in diameter), biotite-rich, two mica leucogranitic body, emplaced in the Contendas Mirante supracrustals and syntectonic with the last phase of deformation (Sabaté et al., 1980). Thermal metamorphism has formed cordierite and andalusite in the surrounding rocks. $\mathrm{Rb} / \mathrm{Sr}$ radiometric measurements give an age of $1.95 \pm 0.05 \mathrm{Ga}$. with an initial of $0.707 \pm$ 0.004 (Sabaté et al., 1990).

\section{Riacho das Pedras}

The Riacho das Pedras pluton represents a small, posttectonic and leucocratic garnetbearing, two mica granite, with muscovite always more abundant than biotite. It is elongate and extends $10 \mathrm{~km}$ in a north - south direction. It was emplaced by magmatic stoping in the Contendas Mirante supracrustals and is associated with numerous tourmalinebearing aplopegmatites. Cordierite nodules have formed in the contact metamorphism aureole. $\mathrm{Rb} / \mathrm{Sr}$ radiometric measurements give an age of $1.93 \pm 0.02 \mathrm{Ga}$ with an initial ratio of $0.748 \pm 0.013$ (Sabaté et al., 1990).

\section{Caetano and Aliança}

The Caetano and Aliança plutons are elongated $20 \mathrm{~km}$ north - south and are only separated by a small isthmus of Contendas Mirante supracrustal rocks east of the Sete Voltas Archaean dome. These two bodies of two mica ( \pm garnet) leucogranite, together with a few smaller ones to the north, probably belong to the same intrusion. Biotitic \pm garnet schlieren and muscovite + biotite + garnet \pm tourmaline pegmatites are common. Metamorphic quartz rods are observed locally in the biotitic schlieren. Hexavalent uranium mineralization occurs along horizontal joints in the Aliança granitic body. Some muscoviterich layers have a higher radioactivity than the homogeneous granite. The pegmatites tend to be aligned along a $\mathrm{N} 25^{\circ} \mathrm{E}-\mathrm{N} 40^{\circ} \mathrm{E}$ foliation.

\section{Lagoa Grande}

The Lagoa Grande pluton $(10 \times 3 \mathrm{~km})$, located close to the southern margin of the Sete Voltas Archaean dome intrudes the Contendas Mirante supracrustal rocks and migmatites from the Gavião basement. This granite is poor in muscovite and very homogeneous. The main magmatic foliation, oriented $N 160^{\circ} \mathrm{E}$, is parallel to the elongation of the pluton and to the regional foliation of the surrounding rocks. This foliation is underlined by biotite \pm garnet schlieren. Subvertical ductile deformation with the same orientation increases eastwards, in the direction of the Sete Voltas dome. Mylonitic textures occur on the eastern margin of the pluton.

\section{Lagoinha}

The very small Lagoinha pluton $(4 \times 1.5$ $\mathrm{km}$ ) is one of the southernmost leucogranitic bodies intruding the Contendas Mirante supracrustal rocks close to a dome of Archaean basement. Biotite and/or muscovite-rich schlieren and muscovite \pm biotite \pm tourmaline pegmatitic pockets are widespread. A ductile vertical foliation oriented $\mathrm{N} 145^{\circ} \mathrm{E}$ tends to align the biotite-rich schlieren and the pegmatites. As in the Lagoa Grande pluton, this deformation increases eastwards.

\section{Sete Voltas TTG suite}

The Sete Voltas TTG suite, which represents 
the largest Archaean dome outcroping in the Contendas Mirante belt, is composed of banded grey gneiss with incipient anatexis and weakly deformed intrusive porphyritic granite. The porphyritic granite is in the central part of the dome.

\section{Mineralogy of the granites}

The proportion of the major mineral phases has been calculated from a biotite mesonorm (Fig. 3). The main variation between the dif-
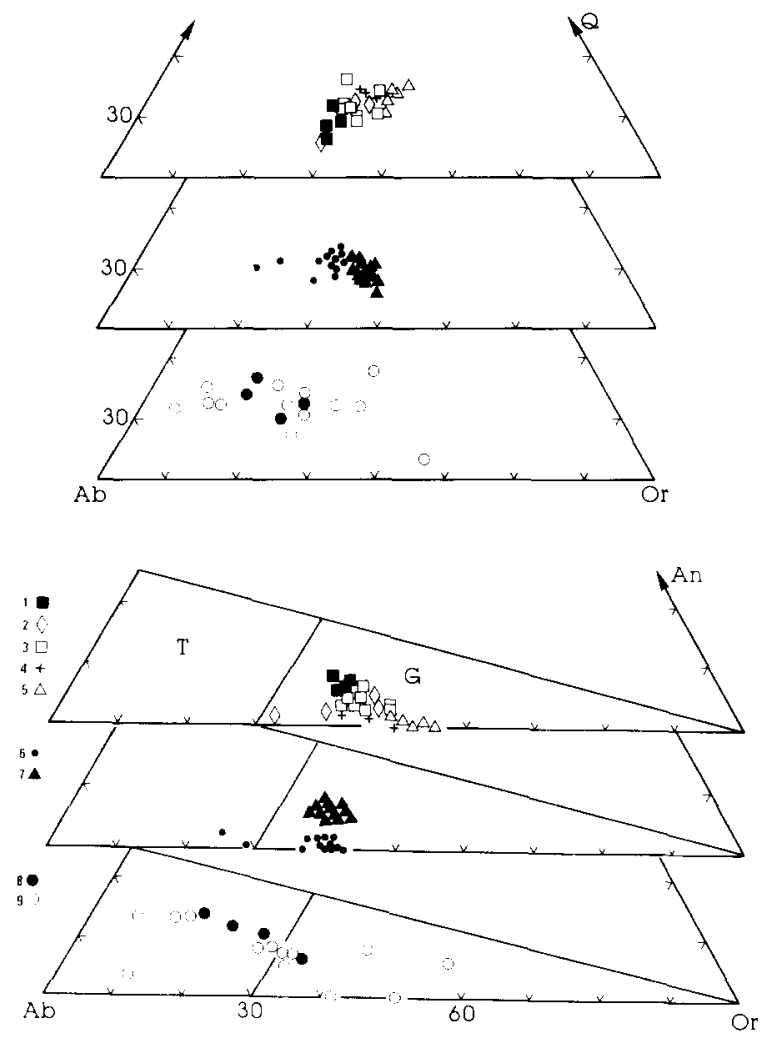

Fig. 3. $\mathrm{Q}-\mathrm{Ab}-\mathrm{Or}$ and $\mathrm{An}-\mathrm{Ab}-$ Or diagrams for the Transamazonian leucogranites and the Sete Voltas Archaean rocks from biotite mesonormative calculations, $I$ = Lagoa Grande; 2 = Carnaíba; 3 = Campo Formoso; 4 = Caetano-Aliança; $5=$ Lagoinha; $6=$ Riacho das Pedras; $7=$ Gameleira; $8=$ Sete Voltas porphyritic; $9=$ Sete Voltas banded; $T=$ Trondhjemite field and $G=$ granite field from O'Connor (1965) defined from catanorm. As the biotite content of rocks studied is low, the difference between catanormative and mesonormative calculations for Or do not exceed $3 \%$. ferent granitic plutons lies in how basic the plagioclase is and the ratio of it to K-feldspar.

The Sete Voltas Archaean plutonic rocks have the highest plagioclase content with the highest anorthite content (up to An35). Their composition varies from trondhjemitic, with less than $10 \% \mathrm{~K}$-feldspar and up to $56 \%$ plagioclase, to granitic. In the banded grey gneiss, mineral proportions may vary considerably within the same outcrop. The porphyritic granites have a more homogeneous mineralogical composition corresponding to the average composition of the foliated grey gneiss.

In the Transamazonian leucogranites, the average proportion of plagioclase and its anorthite content decreases from Lagoa Grande to the Campo Formoso, Gameilera, Carnaíba and Lagoinha plutons (down to $25 \%$ plagioclase). The average proportion of quartz increases slightly from the Lagoa Grande (26.5 wt. \%) to the Campo Formoso (27.5 wt.\%) Carnaíba (28 wt. \%), and Lagoinha (32 wt.\%) granites. The Riacho das Pedras granite is the richest in albite.

In the Transamazonian leucogranites, the biotite content is always below $7 \%$. Only some Archaean plutonic rocks of the Sete Voltas dome contain up to $9 \%$ biotite. The aluminium content in biotite of the leucogranites (15.7 to 19.0 wt. $\% \mathrm{Al}_{2} \mathrm{O}_{3}$ is slighly lower on average than in the biotite of Hercynian peraluminous granites (Fig. 4). Their composition lies on the boundary between the calcalkaline and the aluminopotassic field defined for the French Hercynian granites. The biotite inclusions in quartz give the lowest Al-content. Such an Alcontent is similar to that of the Sete Voltas Archaean trondhjemites and may represent mineral inclusions preserved from the source material. Most of them are also richer in magnesium compared to Hercynian leucogranites. Their fluorine content never exceeds 1.2 wt. $\%$.

Muscovite contents vary from 1 to 14 vol. $\%$. The largest amounts of muscovite have been observed in some samples of the Lagoinha and 


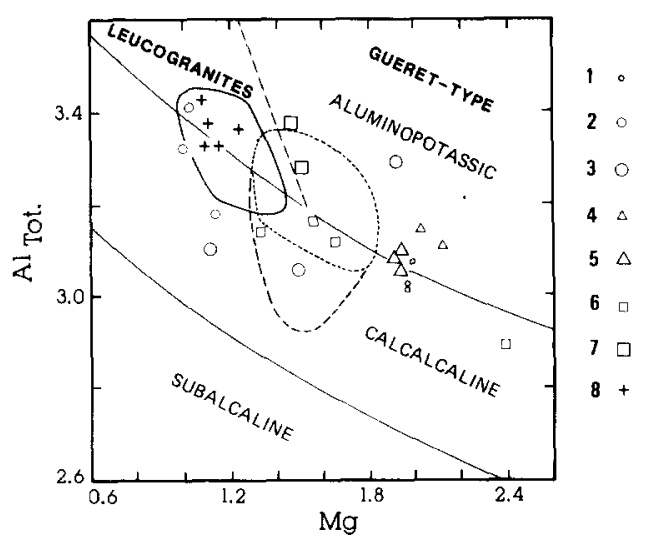

Fig. 4. Al-Mg diagram from Nachit et al. (1985) for selected biotite analysis from the Transamazonian leucogranites and the Sete Voltas Archaean rocks. The compositional field for aluminopotassic (leucocratic muscovite - biotite granite and mesocratic biotite - cordierite Guéret-type peraluminous granites), calcalkaline and subalkaline Hercynian granites are represented. Al and $\mathrm{Mg}$ are in cations per structural formula unit. 1,2 and $3=$ Sete Voltas banded rocks; 4 and $5=$ Lagoinha; 6 and 7 = Campo Formoso; $8=$ Aliança. Fields (data from Rudowski, 1989): dotted line = Campo Formoso biotite from the matrix; stippled line = biotite inclusions in quarts; solid line $=$ Carnaíba biotites.

Campo Formoso plutons. Primary, euhedral and secondary muscovite exist. Euhedral muscovite is generally the most abundant. As observed in Hercynian leucogranites (Monier, 1987), three types of secondary muscovite may be distinguished: symplectitic overgrowths on euhedral crystals; muscovite developed in fissures; and muscovite laths in plagioclase. Their fluorine contents never exceed $0.6 \mathrm{wt} . \%$. The evolution of the fluorine content from the core of the euhedral crystals to the symplectitic muscovite margins does not show significant fluorine enrichment trends as observed in mineralized Hercynian leucogranites (Monier, 1987).

Muscovite is also present in some of the samples of the Sete Voltas banded gneiss. Muscovite is clearly secondary in some of these rocks, having symplectitic textures. Muscovite also occurs as well-developed crystals associat- ed with the main foliation and belonging to the metamorphic paragenesis.

Spessartine-rich garnet is a common mineral in the latest intrusions of the Campo Formoso and Carnaiba plutons and in associated aplopegmatites (Rudowski, 1989). Exceptionally, cordierite may be present in the aplopegmatites.

Tourmaline is common in the pegmatites and in quartz veins, but rare as disseminated crystals in the granites. Beryl and, exceptionally, molybdenite occur in some aplopegmatites of the Campo Formoso and Carnaíba granites.

Hydrothermal alteration with K-metasomatism and quartz leaching similar to the feldspathic Hercynian episyenites (Leroy, 1978; Cathelineau, 1986) has been observed in the Campo Formoso pluton.

Chloritization is common in most of the granites studied but its development is generally very limited. Chlorite is more common in the most differentiated intrusives.

Besides apatite and zircon, allanite and epidote, generally as epitaxic overgrowths on allanite crystals, have been observed in most Transamazonian leucogranites. Magnetite is the main iron oxide in most of the granites. I1menite crystals have only rarely been observed in some samples of the Campo Formoso granite generally associated with magnetite. Monazite is rare, except in the Riacho das Pedras granite, where large crystals with a corona of small automorphic allanite crystals are common. Allanite, epidote and magnetite are also very common in the Sete Voltas Archaean rocks.

\section{Major element geochemistry}

The $A-B$ diagram (Fig. 5) of Debon and Le Fort (1982) shows clearly that all these granites are peraluminous, although the peraluminous index varies largely between and within the different granitic plutons. In the Sete Voltas Archaean plutonic rocks, the most leucocratic samples are the most peraluminous. The porphyritic facies is weakly peraluminous. 


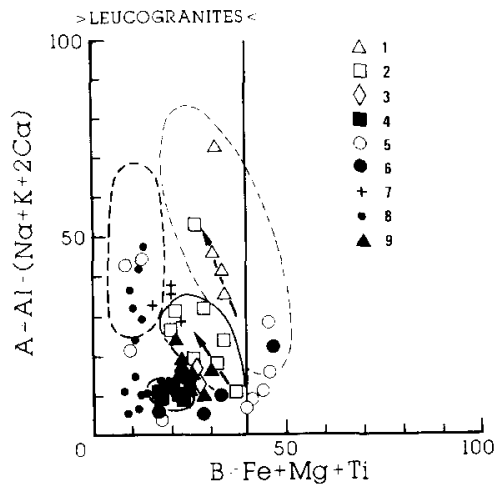

Fig. 5. $A-B$ diagram from Debon and Le Fort (1982) showing the leucocratic and peraluminous character of the Transamazonian leucogranites and the Sete Voltas Archaean rocks. $A$ and $B$ in millications. $l=$ Lagoinha; 2 = Campo Formoso; 3 = Carnaíba; 4 = Lagoa Grande; $5=$ Sete Voltas banded; $6=$ Sete Voltas porphyritic; $7=$ Caetano-Aliança; $8=$ Riacho das Pedras; $9=$ Gameleira. Light stippled line $=$ composition field for the Hercynian Saint Sylvestre granite (unpublished data); heavy stippled line $=$ composition field for the Himalayan Manaslu granite (from Le Fort et al., 1987). The arrows indicate the differentiation trends in a single pluton.

In most Transamazonian leucogranites, the peraluminous index ( $A$ parameter) clearly increases with the degree of differentiation of the granite. In the $A-B$ diagram (Fig. 5) the degree of differentiation is indicated by the decrease in the $B$ parameter which mainly represents the amount of biotite + magnetite in the rock. This trend is typical of Hercynian peraluminous leucogranite. The Lagoa Grande pluton is one of the most leucocratic granites but is the least peraluminous and has a very homogeneous composition. In contrast, the nearby Lagoinha pluton is the most peraluminous and exhibits a very large variation in its peraluminous index, although it is not very leucocratic. The Lagoinha pluton has a composition similar to that of the Saint Sylvestre granite in the French Massif Central, which is a typical example of Hercynian peraluminous leucogranites. The Caetano - Aliança, Campo Formoso and Carnaiba plutons have intermediate characteristics between those of the Lagoa Grande and the Lagoinha pluton. The Campo Formoso pluton has the largest differentiation range, whereas the Carnaiba pluton is homogeneous and leucocratic. The Riacho das Pedras granite is also leucocratic and shows a large variation in the peraluminous index without any significant variation in biotite content. Two sub-groups are distinguished in the $A-B$ diagram for the Riacho das Pedras pluton: one having a low and rather constant peraluminous index; the other a high and variable peraluminous index. These two groups also exhibit distinct trace element compositions. This second trend is identical to that of the Himalayan Manaslu peraluminous leucogranite.

Apart from the Lagoinha and the second sub-group in the Riacho das Pedras granites, the Transamazonian peraluminous leucogranites are distinctly less peraluminous than their Hercynian or Himalayan equivalents. This result is consistent with the lower Al-content of the biotite in the Transamazonian peraluminous leucogranites.

\section{Trace element geochemistry}

\section{Rare earth elements}

The REE have been analyzed by ICP - AES (Govindaraju and Mevelle, 1987) in selected samples of the different leucogranitic plutons and in two samples of the Sete Voltas TTG suite (Table 1, Fig. 6).

The REE pattern of the most trondhjemitic sample of Sete Voltas is typical of Archaean TTG suites with a strong and relatively regular fractionation of all the REE, an extremely weak europium anomaly and a very low HREE content. The more potassic samples have lower LREE content but higher HREE and Y contents and an extremely weak europium anomaly.

The Lagoa Grande and Gameleira samples, and the least differentiated sample of the Carnaiba and Campo Formoso plutons give REE 


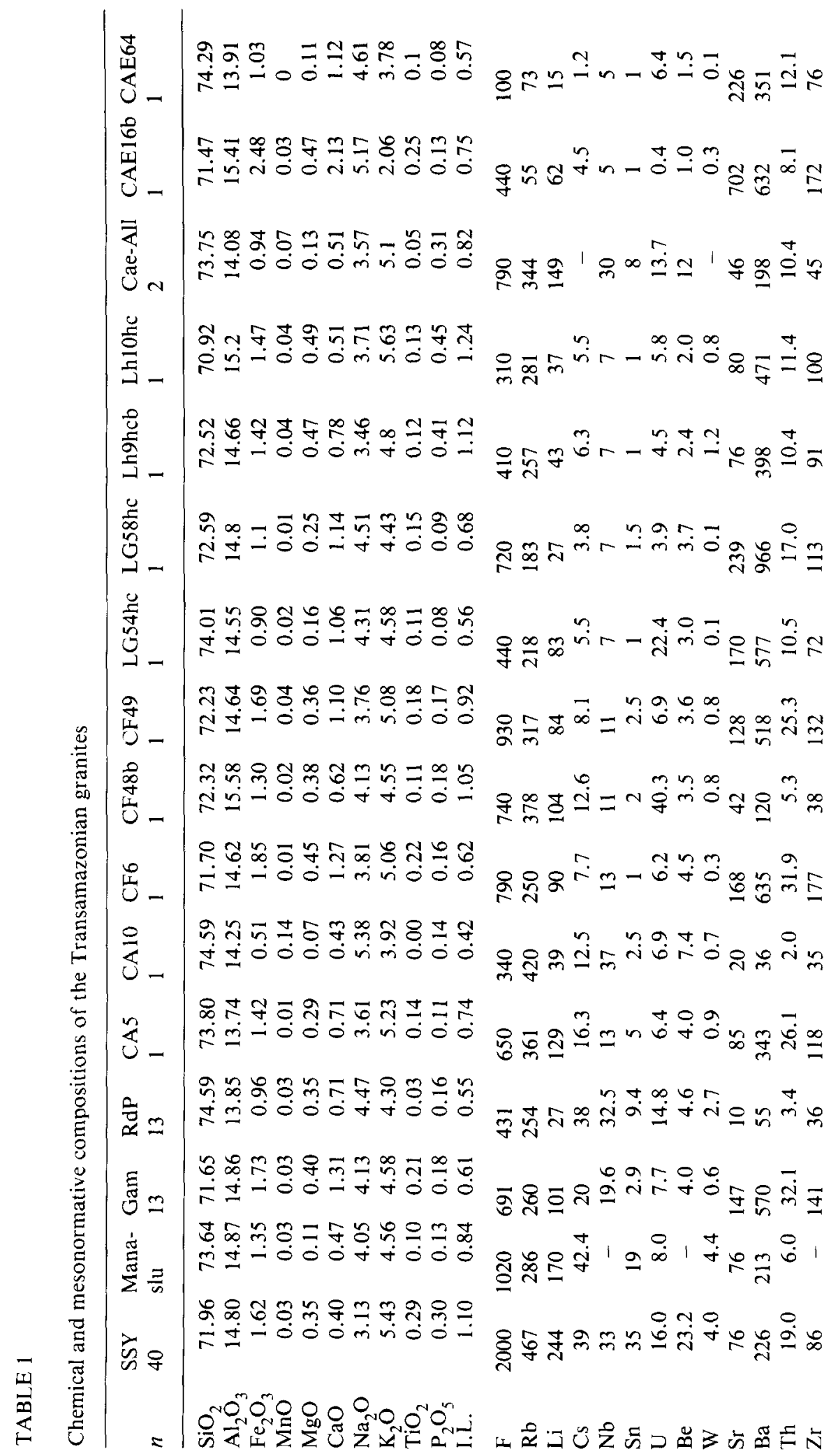




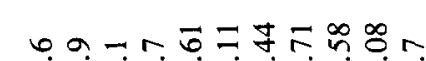

-

ติ -

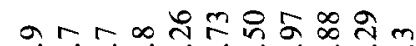

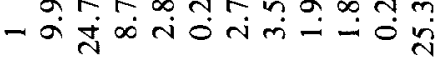

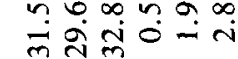

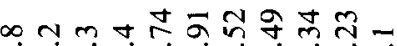

-

$m=\Upsilon 0 \infty m$

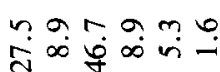

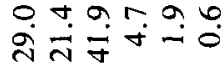

$11 \frac{\pi}{\pi}$

₹

守

桴

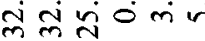

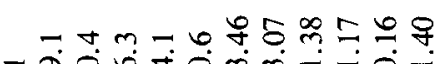

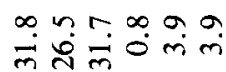

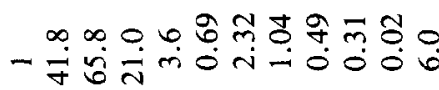

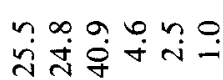

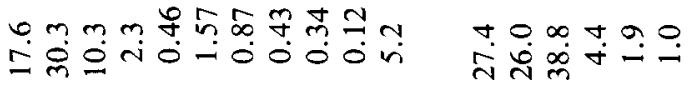

4⿻一𠃋十

-

$\nabla \circ \sim \infty \infty \infty$

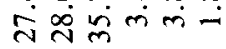

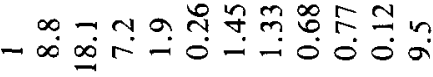

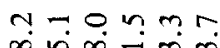

तें

nก

- $\frac{1}{2} \hat{n}^{\infty}-\dot{0}-000$

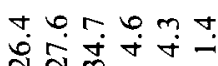

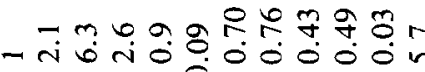

तो

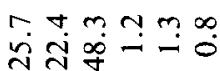

ง 0 으응

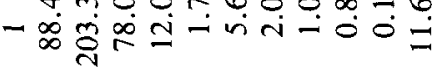

$\infty \sim 0.7+$ तें

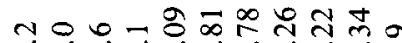

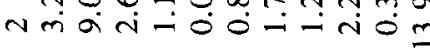

$a, a r o r$

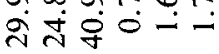

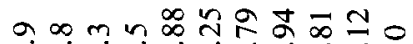

$m \infty 0000$

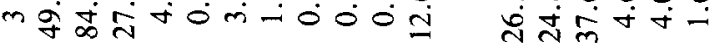

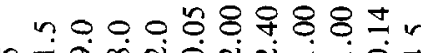

$\forall=2 \infty$ i

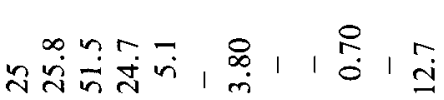

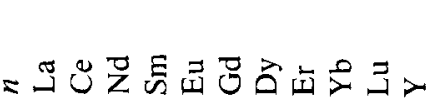

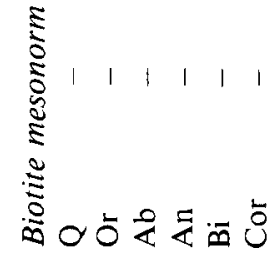

空

0

\&

常

$0 \stackrel{0}{*}$

․․ำ

응

莺苛

位

․․르믈

ठृ क

|| . . สี

40

0

I

을

氜䒺

$11 \frac{2}{8}$

$\nabla$

ฐ

$\ddot{\Xi} \Xi$

总东

2 잉

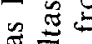

要

รัํํㅇ

象

II

웡 신

拯

iิ

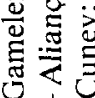

II

2 范

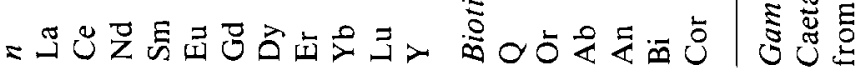



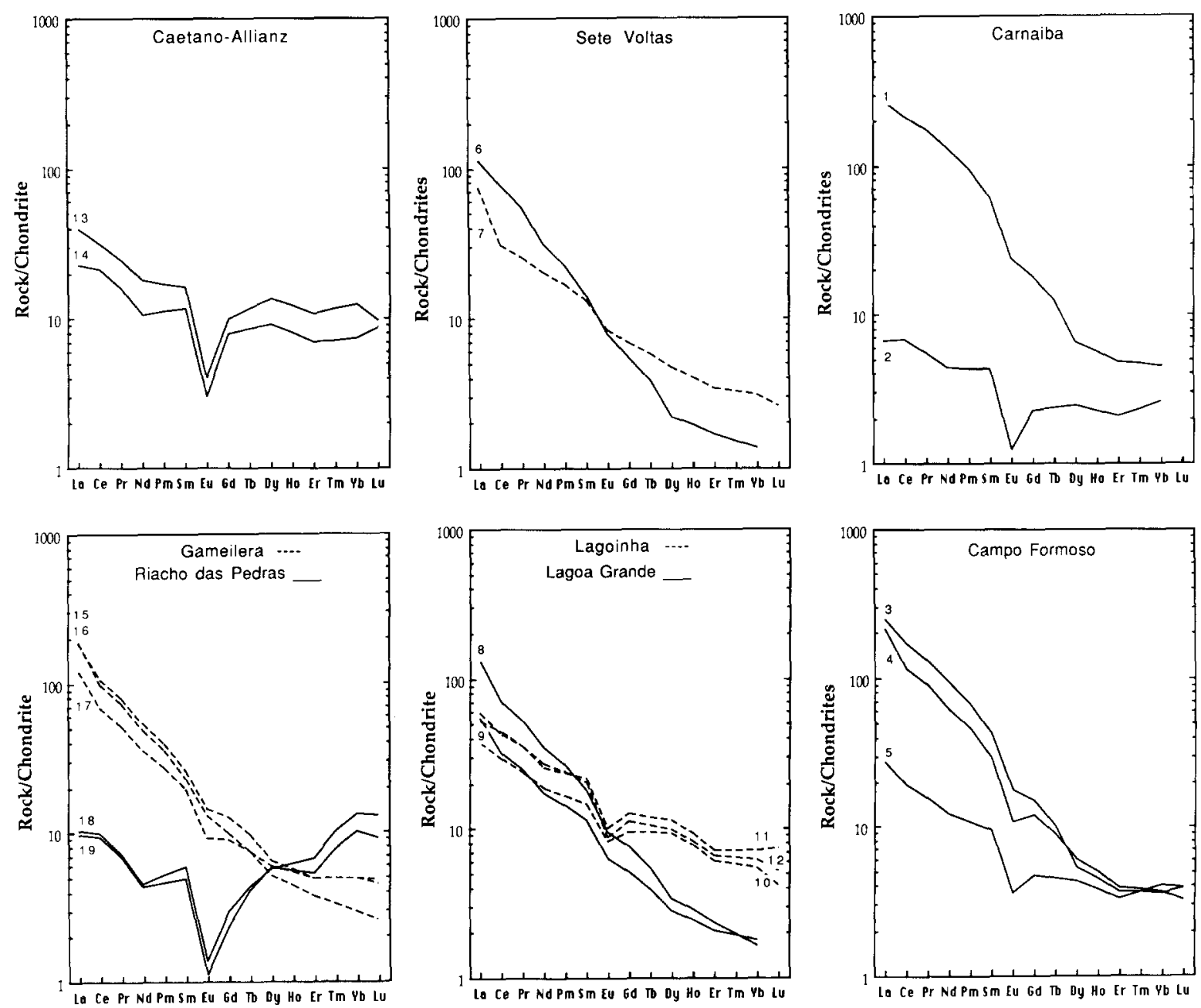

Fig. 6. REE pattern of the Transamazonian leucogranites and the Sete Voltas Archaean rocks. $1=\mathrm{CA} 5,2=\mathrm{CA} 10, \mathrm{Car}-$ naiba; $3=\mathrm{CF} 6,4=\mathrm{CF} 49,5=\mathrm{CF} 48 \mathrm{~b}$, Campo Formoso; $6=\mathrm{CAE} 16 \mathrm{~B}, 7=\mathrm{CAE} 64$, Sete Voltas; $8=\mathrm{G} 58 \mathrm{HC}, 9=$ G54HC, Lagoa Grande; $10=$ G09HCBC, $11=\mathrm{G} 10 \mathrm{HC}, 12=\mathrm{CMS} 88-3$, Lagoinha; $13=\mathrm{CMS} 88-16,14=\mathrm{CMS}$ $88-17$, Caetano-Aliança; $15=$ DMM92, $16=$ DMM95, $17=$ DMM96, Riacho das Pedras; $18=$ DMM92, $19=$ DMM 99L, Gameleira.

patterns very similar to the most trondhjemitic samples of the Sete Voltas dome, suggesting derivation from a source material of similar composition. The Lagoinha, and the more differentiated samples of Carnaiba and Campo Formoso plutons give REE pattern similar to those of Hercynian and Himalayan granites (Vidal et al., 1982, Bernard-Griffiths et al., 1985) with a weaker fractionation of the REE and an important europium anomaly.

The most differentiated samples from a single pluton (Riacho das Pedras) and the most differentiated plutons (Riacho das Pedras and Caetano-Aliança granites) have very low REE contents, "sea-eagle" shaped patterns and the strongest europium anomaly. The decrease of the LREE content with differentiation is similar to that observed in more recent 
leucogranites but mainly corresponds to allanite fractionation in the Transamazonian leucogranites instead of monazite.

\section{Other trace elements}

The other trace elements have been normalized to a typical Hercynian peraluminous leucogranite from the French Massif Central (Fig. 7) associated with major uranium deposits and numerous $\mathrm{Sn}-\mathrm{W}$ mineralizations (Saint Sylvestre). Incompatible elements are plotted on the left of the figure, whereas compatible elements are plotted on the right of the figure.

The two samples of the Sete Voltas Archaean gneiss dome are extremely poor in all incompatible elements, except uranium for the most
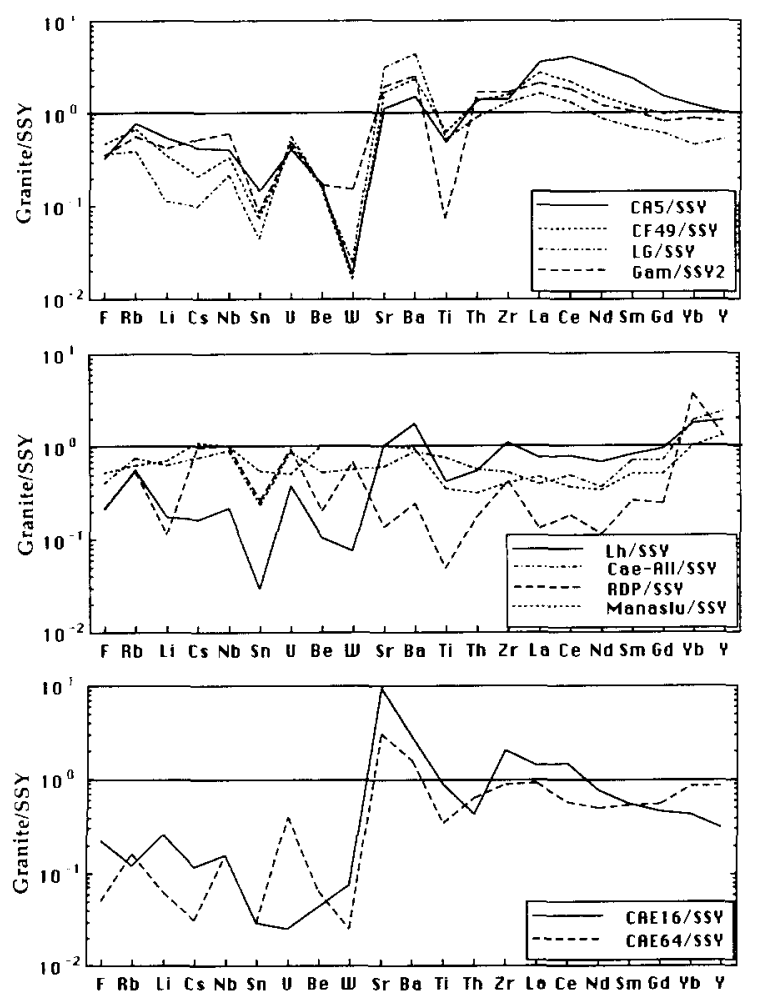

Fig. 7. Graphs of the Transamazonian leucogranites, the Himalayan Manaslu granite and the Sete Voltas Archaean rocks normalized to the Hercynian Saint Sylvestre (SSY) peraluminous leucogranite. (Same abbreviations as Table 1). granitic composition. Sr and Ba have high values characteristic of such rock types. The most trondhjemitic sample has a more fractionated REE pattern but a similar total REE content.

Most of the Transamazonian leucogranites exhibit very similar patterns. They have a much lower incompatible element content than the Saint Sylvestre granite, especially in Sn and W, but are as enriched in $\mathrm{Sr}$ and $\mathrm{Ba}$ as the TTG gneisses. REE patterns are generally more fractionated for the Transamazonian leucogranites apart from the Lagoinha and Riacho das Pedras granites and the Caetano-Aliança plutons. The Riacho das Pedras and the Caetano - Aliança granites represent the most differentiated Transamazonian leucogranites with very low $\mathrm{Sr}, \mathrm{Ba}, \mathrm{Ti}, \mathrm{Zr}$, Th and REE contents similar to the Himalayan Manaslu peraluminous leucogranite and the same Cs, $\mathrm{Nd}$ and $\mathrm{U}$ enrichment as the Hercynian Saint Sylvestre peraluminous leucogranite. Despite the highly fractionated character of the Riacho das Pedras granite, F, Li, Sn and W concentrations remain very low.

The different granitic massifs, and even several units with in the same granitic body, as in the Gameleira granite, can be also characterized by their trace element ratios such as $\mathrm{Zr} / \mathrm{Sr}$

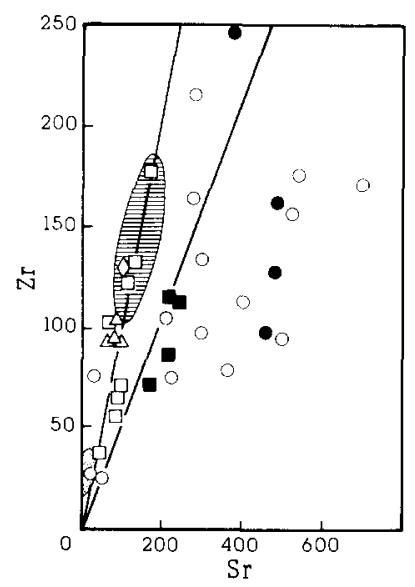

Fig. 8. $\mathrm{Zr} / \mathrm{Sr}$ diagram for the Transamazonian leucogranites and the Sete Voltas Archaean rocks. Same symbols as Figure 3 excepted: dotted field for Riacho das Pedras granite and hatched field for Gameleira granite. 


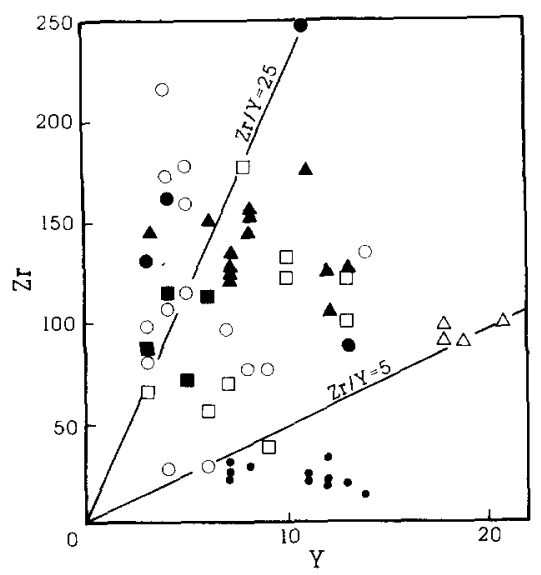

Fig. 9. $\mathrm{Zr} / \mathrm{Y}$ diagram for the Transamazonian leucogranites and the Sete Voltas Archaean rocks. Same symbols as Figure 3.

and $\mathrm{Zr} / \mathrm{Y}$ (Figs. 8 and 9). In the $\mathrm{Zr} / \mathrm{Y}$ diagram, two sub-groups can be clearly distinguished in the Gameleira and in the Riacho das Pedras plutons. Two parallel differentiation trends have also been distinguished in the Campo Formoso pluton from trace element data (Rudovski, 1989). The composition of the Sete Voltas Archaean rocks encompasses most of the composition field defined by the Transamazonian leucogranites with the exception of the Lagoinha and Riacho das Pedras granites in the $\mathrm{Zr} / \mathrm{Y}$ diagram.

\section{Interpretation and conclusions}

\section{Granitoid types}

The Sete Voltas rocks represent an unusual petrographic association for an Archaean TTG suite. Their composition varies from trondhjemitic to rather potassic granites, and some of them are strongly peraluminous. The strongly peraluminous character is marked by the presence of muscovite. Part of this muscovite is clearly secondary and related to the last deformation episode corresponding to the emplacement of the earliest generation of leucogranites. Some of the muscovite may also reflect either a primary peraluminous composition or results from a pre-metamorphic alteration and/or deformation episode, but we have no definite argument to support either hypothesis. What is certain is that some of the Archaean rocks were already peraluminous before (or at least became peraluminous during) the Transamazonian orogeny. The alteration of initially meta-aluminous rocks into peraluminous rocks during deformation and metamorphism by alkalis and/or calcium leaching is a well-known phenomenon (Marquer et al., 1985).

Most of the Transamazonian leucogranites of the Jacobina-Contendas Mirante belt follow the typical evolution trend of Hercynian peraluminous leucogranites, namely a strong increase in the peraluminous index with decreasing mafic mineral content. This trend differs greatly from the trends in other peraluminous granites. In the S-type suites (White and Chappel, 1977), a decrease in the peraluminous index with decreasing mafic mineral content, corresponding well to the restite unmixing model, is observed. Two granites present different trends: the most peraluminous group of the Riacho das Pedras granite shows the same evolution as the Himalayan Manaslu granite, in which biotite content remains constant with the increase in the peraluminous index. The Lagoa Grande granite and the less peraluminous group of the Riacho das Pedras granite are weakly peraluminous and may have formed either from direct partial melting of a weakly peraluminous source or from the extreme fractionation of a calcalkaline suite. The lack of associated intermediate or basic plutonic rock favours the first hypothesis.

Most of the Transamazonian leucogranites are less peraluminous than their Hercynian or Himalayan equivalents (Table 1). Biotite-rich samples are less peraluminous and biotite composition is less aluminous. The characteristics of the source material from which these granites derive may explain these features. Highly peraluminous sediments are less abundant in Archaean crust whereas meta-aluminous meta- 
igneous rocks are abundant. Therefore the main source material may consist of metaigneous plutonic or volcanic formations similar to the Sete Voltas Archaean TTG suite. Evidence for such a source is further supported by the mineralogical characteristics of the granite discussed below. A metapelitic component may, however, be important in the Riacho das Pedras and Lagoinha granites.

\section{Genetic model}

The trends defined by the trace elements, mainly the decreasing content of incompatible elements with decreasing titanium content in the Campo Formoso and Carnaiba pluton, have been explained in terms of fractional crystallization of a meta-aluminous source $(\mathrm{Ru}-$ dowski and Fonteilles, 1988). However, the increase in the peraluminous character, which is a major feature of many of these granites and is also reflected by the increasing $\mathrm{Al}$-content of biotite with decreasing abundance of compatible elements (Rudowski and Fonteilles, 1988), cannot be explained by this model and is the opposite of the "restite unmixing model" of White and Chapel (1977). The evolution observed in the peraluminous leucogranites requires the fractionation of a meta-aluminous mineral phase such as pyroxene or amphibole, which has never been observed in this type of granite. The lack of any associated mafic or intermediate enclaves or plutonic units also does not support the fractional crystallization model and/or mixing with a basic igneous component.

The different trends observed within and between the different intrusions are assumed to result from the heterogeneity of the source material. The heterogeneity of the source material within the same pluton has been clearly supported by data on the radiogenic and stable isotopes from the very recent Manaslu peraluminous leucogranite (Vidal et al., 1982; FranceLanord et al., 1988) but such a demonstration is more difficult on such an old system as the
Transamazonian leucogranites. However two samples from the Campo Formoso pluton with very distinct $\epsilon \mathrm{Nd}(\mathrm{t})$ support the theory of heterogeneous source material within the same intrusion.

\section{The source problem}

One of the major characteristics of the Transamazonian peraluminous magmas is the occurrence of the magnetite - allanite accessory mineral association instead of the ilmenite monazite assemblage generally observed in most Himalayan and Hercynian leucogranites. The presence of allanite instead of monazite is generally related to the high $\mathrm{Ca}$ content (CaO $\geq 1 \mathrm{wt} . \%$ ) of the silicate melt (see Cuney and Friedrich (1987) for a review of this problem), but most of the Transamazonian leucogranites have a $\mathrm{CaO}$ content well below $1 \mathrm{wt} . \%$. Oxygen fugacity is another important parameter controlling epidote stability (Liou, 1973). Although no experimental data on allanite are available, we should expect the stability of this mineral to be very close to that of epidote. Under the reducing conditions (close to or below the $\mathrm{Ni}-\mathrm{NiO}$ buffer) commonly prevailing in peraluminous granites (Ishihara, 1977) and for a pressure of crystallization below $3 \mathrm{kbar}$, epidote is stable below $600^{\circ} \mathrm{C}$ and therefore cannot crystallize at the magmatic stage. Higher oxygen fugacity closer to the haematite - magnetite buffer allows epidote crystallization at $640-680^{\circ} \mathrm{C}$ for a pressure of $2-3 \mathrm{kbar}$. High oxygen fugacity in the Transamazonian leucogranitic magmas is also indicated by the scarcity of ilmenite and the general occurrence of magnetite. The relatively magnesian character of the biotite compared to equivalent Hercynian granites can probably be explained in the same way, because the $\mathrm{Fe} / \mathrm{Fe}+\mathrm{Mg}$ ratio of biotite decreases with oxygen fugacity (Wones and Eugster, 1965). Such features directly reflect the lack or the low abundance of graphitebearing sediments in the source material of these granites and corroborate the pre-domi- 
nantly meta-igneous character of this source material. This represents a major difference to the predominantly metasedimentary source material generally proposed for Hercynian and Himalayan leucogranites (Le Fort et al., 1987; Vidal et al., 1982, 1984; Bernard-Griffiths et al., 1985).

The major and trace element composition field of the Sete Voltas Archaean TTG suite is very large and encompasses the compositional field of the porphyritic granites outcropping in the Sete Voltas dome and also that of most Transamazonian leucogranites, apart from the Lagoinha pluton. The variation in the peraluminous index and the accessory mineral paragenesis characterized by magnetite and allanite/epidote also corresponds to that of the Transamazonian leucogranites. Mineralogical and chemical signatures therefore support the idea that the Archaean TTG suites may represent a possible source material for the Transamazonian leucogranites.

The parallel or divergent trends existing in the different plutons which led to the evolution of peraluminous character, and the fractionation of major and trace elements, reflect variations in the source composition and the melting conditions.

The high strontium initial ratios $(0.7065-$ $0.7331)$ and the low $\epsilon \mathrm{Nd}$ values ( -4.9 to -13.1) measured on some of these granites (Sabaté et al., 1990) support the idea that they originated from the partial melting of continental crust of probable Archaean age and that the source composition varied. However Nd model ages $(2.42-3.17 \mathrm{Ga})$, tend to rule out the Boa Vista and Mata Verde TTG suites (3.1 - 3.5 Ga, Cordani et al., 1985) as a source for the Transamazonian granites. Isotopic data favour the Gavião medium grade terrains as a possible source for these granites (Sabaté et al., 1990). Isotopic data for the Sete Voltas dome are necessary to give further constraints on the possible source of the granites.

\section{Metallogenic potential}

The Jacobina - Contendas Mirante peraluminous leucogranites have low concentrations of the incompatible elements, $\mathrm{Li}, \mathrm{F}, \mathrm{Cs}$, and $\mathrm{Be}$, and metals such as Sn and W compared to mineralized Hercynian granites (Table 1 and Fig. 7). The Carnaíba granite associated with one of the most important emerald mineralizations is not the richest in incompatible elements. Despite the occurrence of beryl and molybdenite locally in the aplopegmatites, and of molybdenite + scheelite associated with emerald in the metasomatic veins, the $\mathrm{Be}, \mathrm{Mo}$ and $W$ contents of the Carnaiba granite remain very low. As proposed by Rudowski (1989), the importance of these mineralizations results mainly from the efficiency of the metasomatic trap. Although the Riacho das Pedras granite shows much differentiation, its enrichment in incompatible elements remains relatively low, except for $\mathrm{Cs}, \mathrm{Nb}$, and $\mathrm{U}$; perhaps reflecting the primitive nature of the crustal material that underwent partial melting during the Transamazonian orogenesis.

Uranium enrichment in the Riacho das Pedras and Caetano - Aliança granites is similar to that of the Hercynian Saint Sylvestre peraluminous leucogranite associated with major uranium deposits. They represent the most favourable granitic bodies for the occurrence of uranium deposits. Uranium mineralizations have been observed in the Caetano-Aliança pluton which is the richest in incompatible elements of all the Transamazonian leucogranites. The recognition of episyenites in the Campo Formoso pluton similar to those described in the Hercynian leucogranites, where they represent a trap for many economic uranium deposits, is another favourable criterion for proposing the possible existence of uranium mineralization in the Transamazonian peraluminous leucogranites. 


\section{The geotectonic model}

A continental collision regime at $2 \mathrm{Ga}$ between two Archaean crustal domains, in the São Francisco craton, is supported by several features. Regional scale westward overthrusting is well known in the Jacobina area and is becoming well-documented in the Contendas Mirante area. Intrusive igneous rocks observed in the Jacobina - Contendas Mirante belt share many characteristics with Hercynian and Himalayan syncollision magmatism. They form a $500 \mathrm{~km}$ elongate belt of typical synkinematic to postkinematic peraluminous leucogranites parallel to the major thrust planes. The high $\mathrm{Rb}$ content of these granites for a relatively low $\mathrm{Nb}+\mathrm{Y}$ content are consistent with a syncollision tectonic environment during their genesis according to the Pearce et al. (1984) classification (Fig. 10). Characteristically, associated intermediate to basic plutonism is totally lacking in these plutons. Although some of the granites are emplaced as

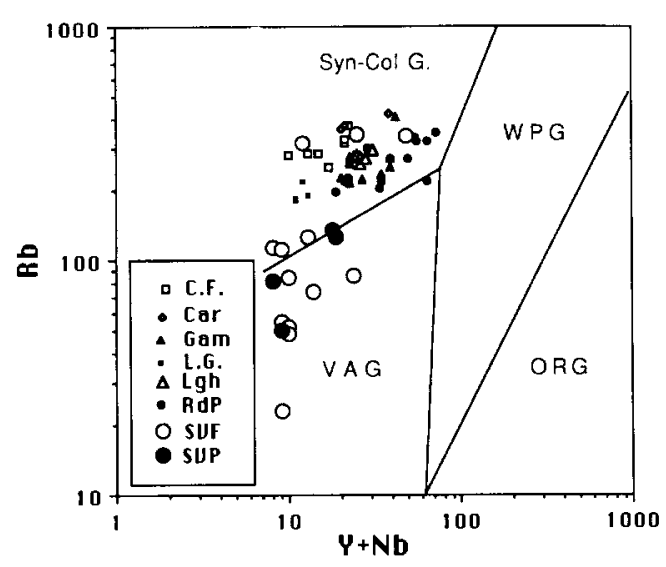

Fig. 10. $\mathrm{Rb} / \mathrm{Nb}+\mathrm{Y}$ diagram from Pearce et al. (1984) showing the syn-collision geochemical characteristics of the Transamazonian leucogranites and some of the Sete Voltas Archaean rocks. Most samples from the Sete Voltas have compositions very poor in $\mathrm{Y}$ and $\mathrm{Nb}$ and plot in the volcanic arc - granite field. $C F=$ Campo Formoso; Car = Carnaíba; Gam = Gameleira; L.G. = Lagoa Grande; $L g h=$ Lagoinha; $R d P=$ Riacho das Pedras; $S V F=$ Sete Voltas banded; $S V P=$ Sete Voltas porphyritic. Syn-Col $G$. = syn-collision granites. circular diapirs, most of them are lenticular bodies with internal magmatic structures and an elongation parallel to the major thrust planes, as in the High Himalaya belt. They are generally located in the vicinity of the disharmonic boundary between the Archaean infrastructure, the Gavião block, and a superstructure, the Jacobina - Contendas Mirante supracrustal rocks. This relationship is similar to that observed in the central part of the Himalayan chain, where the infrastructure is the Tibetan slab and the superstructure the High Himalaya Tethyan sedimentary sequence (Le Fort, 1981). Thus, if such a comparison is valid, the equivalent of the Main Central Thrust (MCT) should be searched far below the Archaean granitogneissic unit further to the west. It may correspond to the tangential structure identified by Sabate et al. (1988) in the Aracatu dome in the Gavião block, the northern extention of which is unfortunately concealed by a late Proterozoic sedimentary basin.

\section{Acknowledgments}

The results presented in this paper constitute a contribution of the CNRS-INSU program "Dynamique et Bilan de la Terre" and of the project "Granitóides da Bahia: geologia e metalogenêse" which receives financial support through agreements FINEP (PADCT)/ UFBA, CNPq/ORSTOM, SGME-SME (Ba)/ UFBA and CNEN/UFBA. The authors thank H. Martin, G. Giuliani and two anonymous reviewers for constructive comments and revision of the English text.

\section{References}

Barbosa, J.S., 1986. Constitution lithologique et métamorphique de la région granulitique du sud de Bahia. Ph. D. Thesis, Univ. Paris, 401 pp. (unpubl.).

Bernard-Griffiths, I., Peucat, J.J., Sheppard, S.M.F. and Vidal, P., 1985. Petrogenesis of Hercynian leucogranites from the southern Armorican Massif: contribution of REE and isotopic ( $\mathrm{Sr}, \mathrm{Nd}, \mathrm{Pb}$ and $\mathrm{O}$ ) geochemical data to the study of source rocks charac- 
teristics and ages. Earth. Planet. Sci. Lett., 74: 235250.

Cathelineau, M., 1986. The hydrothermal alkali metasomatism effects on granitic rocks: quartz dissolution and related subsolidus changes. J. Petrol., 27 (4): $945-965$.

Celino, J.J. and Sabaté, P., 1988. O Macico de Jaguarari: uma intrusão granítica de vocação crustal na margem do cinturão transamazonico da Serra de Jacobina (Bahia, Brasil). Congr. Lat. Am. Geol., 7th (Bélem, Brasil), p. 437. abstr.

Conceiçãao, H., 1986. Os granitos do rio Caveira: petrologia de intrusoes precambrianas no cisalhamento axial do complexo Contendas Mirante (Bahia, Brasil). M. Sc. Thesis, Bahia Federal Univ., 248 pp. (unpubl.).

Cordani, U.G., Sato, K. and Marinho, M.M., 1985. The geologic evolution of the ancient granite - greenstone terrane of central-southern Bahia, Brazil. Precambrian Res., 42: 1- 17.

Couto, P.A., 1978. Projeto Serra de Jacobina Relatório final. Vol. 3. pp. $850-861$.

Cuney, M. and Friedrich, M., 1987. Physicochemical and crystal chemical controls on accessory mineral paragenesis in granitoids. Implications on uranium metallogenesis. Bull. Minéral., 110: 235 - 247.

Debon, F. and Le Fort, P., 1982. A chemicalmineralogical classification of common plutonic rocks and associations. Trans. R. Soc. Edinburgh: Earth Sci., 73: $135-149$.

De la Roche, H., Stussi, J.M. et Chauris, L., 1980. Les granites à deux micas hercyniens français. Essai de cartographie et de corrélations géochimiques appuyés sur une banque de données. Implications pétrologiques et métallogéniques. Sci. Terre, 24 (1): 5- 121.

Deniel, C., Vidal, P., Fernandez, P., Le Fort, P. and Peucat, J.J., 1987. Isotopic study of the Manaslu granite (Himalaya, Nepal): inferences on the age and source of Himalayan leucogranites. Contrib. Mineral. Petrol., 96: 78-92.

France-Lanord, C. and Le Fort, P. 1988. Crustal melting and granite genesis during the Himalayan collision orogenesis. Trans. R. Soc. Edinburgh: Earth Sci., 79: 183-195.

France - Lanord, C., Sheppard, S.M.F. and Le Fort, P., 1988. Hydrogen and oxygen isotope variations in the High Himalaya peraluminous Manaslu leucogranite: evidence for heterogeneous sedimentary source. Geochim. Cosmochim. Acta, 52: 513-526.

Friedrich, M., Cuney, M. and Poty, B., 1987. Uranium geochemistry in peraluminous leucogranites. Uranium, 3: $353-385$.

Govindaraju, K. and Mevelle, G., 1987. Fully automated dissolution and separation method for inductively coupled plasma atomic emission spectrometry rock analysis. J. Anal. At. Spectrom., 2: 615-621.

Ishihara, S., 1977. The magnetite-series and the ilmenite series in granitic rocks. Min. Geol. Spec., 27: $293-305$.

Le Fort, P., 1981. Manaslu leucogranite: a collision signature of the Himalaya, a model for its genesis and emplacement. J. Geophys. Res., 86 (B11): 104545 - 10568.

Le Fort, P., Cuney, M., Deniel, C., France - Lanord, C., Sheppard, S.M.F., Upreti, B.N. and Vidal, P., 1987. Crustal generation of the Himalayan leucogranites. Tectonophysics, 134: $39-57$.

Leroy, J., 1978. The Margnac and Fanay uranium deposits of the La Crouzille district (Western Massif Central), geologic and fluid inclusion studies. Econ. Geol., 73: 1611 - 1634 .

Liou, J.G., 1973. Synthesis and stability relations of epidote, $\mathrm{Ca}_{2} \mathrm{Al}_{2} \mathrm{FeSi}_{3} \mathrm{O}_{12}(\mathrm{OH})$. J. Petrol., 14 (3): $381-413$.

Marinho, M.M. and Sabaté, P., 1982. The Contendas Mirante volcanosedimentary sequence and its granitic-migmatitic basement. In: Int. Symp. Archean and Early Proterozoic Geologic Evolution and Metallogenesis. CPM/SME-Bahia, Salvador, Brazil, Vol. 1, pp. 139-184 (abstr.).

Marinho, M.M., da Silva, E.F.A., Soares, J.V. and Costa, P.H., 1979. Proj. Contendas-Mirante. C.B.P.M., Conv. CBPM-SME-Bahia, Salvador, relatório final, Vol. 1, 255 pp. (unpubl.).

Marinho, M.M., da Silva, E.F.A., Lopes, G.A.D.C., Soares, J.V. and Cruz, M.J.M., 1980. Projeto Anagé - Caldeirão C.B.P.M., Conv. CBPM-SMEBahia, Salvador, relatório final, Vol. 1, 203 pp. (unpubl.).

Marquer, D., Gapais, D. and Capdevilla, R., 1985. Comportement chimique et orthogneissification d'une granodiorite en faciès schistes verts (Massif de L'Aar, Alpes Centrales). Bull. Minéral., 108: 209-221.

Mascarenhas, J. de F., 1973. A geologia do centro oriental da Bahia. In: Annu. Congr. Bras. Geol., 27th (Aracaju), Soc. Bras. Geol., Vol. 2, pp. 35-66.

Mascarenhas, J. de F., 1976. Geologia da região centro oriental da Bahia. Proj. Bahia II-Sul da Bahia-CPRM, Conv. DNPM/CPRM (Salvador, Bahia, Brasil), relatório final.

Monier, G., 1987. Cristallochimie des micas des leucogranites. Nouvelles données expérimentales et applications pétrologiques. Géol. Géochim. Uranium Mém., 14: 347 pp.

Monier, G. and Robert, J.L., 1986. Evolution of the miscibility gap between muscovite and biotite solid solutions with increasing lithium content: an experimental study in the system $\mathrm{K}_{2} \mathrm{O}, \mathrm{LiO}_{2}, \mathrm{MgO}, \mathrm{FeO}$, $\mathrm{Al}_{2} \mathrm{O}_{3}-\mathrm{SiO}_{2}-\mathrm{H}_{2} \mathrm{O}$, HF at $600^{\circ} \mathrm{C}, 2 \mathrm{kbar} \mathrm{pH}_{2} \mathrm{O}$ : comparison with natural lithium micas. Mineral. 
Mag., 50: 641-650.

Nachit, H., Razafimahefa, N., Stussi, J.M. and Carron, J.P., 1985. Composition chimique des biotites et typologie magmatique des granitoides. C.R. Acad. Sci., Sér. 2, 301: 1539-1551.

O'Connor, J.T., 1965. A classification for quartz rich igneous rocks based on feldspar ratios. U.S. Geol. Surv. Prof. Pap., 525-B: $1379-1384$.

Pearce, J.A., Harris, N.B.W. and Tindle, A.G., 1984. Trace element discrimination diagrams for the tectonic interpretation of granitic rocks. J. Petrol., 25: 956-983.

Pichavant, M., Kontak, D.J., Herrera, J.V. and Clark, A.H., 1988a. The Miocene-Pliocene Macusani volcanics, SE Peru. I. Mineralogy and magmatic evolution of a two-mica aluminosilicate-bearing ignimbrite suite. Contrib. Mineral. Petrol., 100: $300-324$.

Pichavant, M., Kontak, D.J., Briqueu, L., Herrera, J.V. and Clark, A.H., 1988b. The Miocene-Pliocene Macusani volcanics, SE Peru. II. Geochemistry and origin of a felsic peraluminous magma. Contrib. Mineral. Petrol., 100: 325-338.

Rudowski, L., 1989. Pétrologie et géochimie des granites transamazoniens de Campo Formoso et Carnaíba (Bahia, Brésil), et des phlogopitites à émeraude associées. Thesis, Univ. Paris, 282 pp. (unpubl.).

Rudowski, L. and Fonteilles, M., 1988. Existence de deux séries évolutives distinctes dans les granites peralumineux de Campo Formoso, et leurs relations avec les granites de Carnaíba et les minéralisations à émeraudes (Serra de Jacobina, Bahia, Brésil). C.R. Acad. Sci., Sér. 2, 307: 935 - 940.

Rudowski, L., Giuliani, G. and Sabaté, P., 1987. Les phlogopitites à émeraudes au voisinage des massifs de Campo Formoso et de Carnaíba (Bahia, Brésil): un exemple de minéralisations protérozoíques à $\mathrm{Be}$, Mo et W dans des ultrabasites métasomatisées/ C.R. Acad. Sci., Sér. 2, 304: 1129-1134.

Sabaté, P., Machado, G.V.M., da Silva and de Souza, M.Z.A. 1980. Données structurales des formations précambriennes épimétamorphiques du complexe Contendas Mirante (Bahia, Brésil). Cah. ORSTOM
Sér. Géol., 11 (1): $18-24$.

Sabaté, P. Gomes, L.C.C. and dos Anjos, J.A.A., 1988. Nota explicativa do mapa temático "Granitogênese da Bahia" - folha a 1/250 000. Vitoria da Conquista, SGN-SME/Bahia, Salvador.

Sabaté, P., Marinho, M.M., Vidal, P. and CaenVachette, M., 1990. The $2 \mathrm{Ga}$ peraluminous magmatism of the Jacobina-Contendas Mirante belts (Bahia, Brazil): geologic and isotopic constaints on the sources. Chem. Geol., 83: 325-338.

Stussi, J.M. and De la Roche, H., 1984. Le magmatisme orogénique granitique de la chaîne varisque française. Typologie chimique et répartition spatiale. C.R. Acad. Sci., Sér. 2, 298: $43-48$.

Torquato, J.R., Tanner de Oliveira, M.A.F. and Bartels, R.L., 1978. Idade radiométrica do granito de Campo Formoso, Bahia. Uma idade mínima para o Grupo Jacobina. Rev. Bras. Geochem., 8: 171-179.

Turpin, L., Maruejol, P. and Cuney, M., 1988. Comparative $\mathrm{U}-\mathrm{Pb}, \mathrm{Rb}-\mathrm{Sr}$ and $\mathrm{Sm}-\mathrm{Nd}$ chronology of granitic basement, hydrothermal albitites and uranium mineralization (Lagoa Real, South-Bahia, Brasil). Contrib. Mineral. Petrol., 98: 139-147.

Vidal, P., Cocherie, A. and Le Fort, P., 1982. Geochemical investigations of the origin of the Manaslu leucogranite (Himalaya, Nepal). Geochim. Cosmochim. Acta, 46: 2279-2292.

Vidal, P., Bernard - Griffiths, J., Cocherie, A., Le Fort, P., Peucat, J.J. and Sheppard, S.M.F., 1984. Geochemical comparison between Himalayan and Hercynian leucogranites. Phys. Earth Planet. Inter., 35: $179-190$.

White, A.J.R. and Chappel, B.W., 1977. Ultrametamorphism and granitoid genesis. Tectonophysics, 43: $7-22$.

Wilson, N., 1987. Combined $\mathrm{Sm}-\mathrm{Nd}, \mathrm{Pb}-\mathrm{Pb}$ and $\mathrm{Rb}-\mathrm{Sr}$ geochronology and isotope geochemistry in plymetamorphic Precambrian terrains: Examples from Bahia, Brazil and Channel Islands, UK. M. Sc. Thesis, Oxford Univ., 64 pp. (unpubl.).

Wones, D.R. and Eugster, H.P., 1965. Stability of biotite/experiment, theory and application. Am. Mineral., 50: $1228-1272$. 